\title{
The Cyclone As Catalyst
}

\author{
Ute Haring and Reesa Sorin
}

\author{
James Cook University
}

\begin{abstract}
Cyclones are endured, but often dreaded in tropical regions such as Far North Queensland. Memories, and often myth, of their destructive effects permeate written, visual and spoken text from and about this area. This paper presents findings from a qualitative research project which examined the impact of tropical north Queensland's 2006 Cyclone Larry on children's wellbeing, as expressed through their drawings and narratives, using Haring's (2012) Content, Interpretive and Developmental (CID) method for analysis. This research is presented through the three stages of a cyclone: the lead up, landfall and finally the aftermath, or lessons learned. Experiences of children during these three stages, as conveyed in the publication, Cyclone Larry. Tales of survival from the children of North Queensland (Mothers Helping Others [MHO], 2006) are examined and discussed to present a broad perspective about how children express fear, resilience and hope for the future.

In this study children are seen as active participants and not victims. Art and narratives give children a voice through which to express feelings, as well as being a tool for healing and encouraging children's resilience. Findings to date suggest that children's perspectives supply significant contributions to our understandings of natural disasters such as cyclones.
\end{abstract}

Key Words: Far North Queensland, Children and disaster, impacts of cyclones, children's drawings and narratives, CID Method, qualitative research

\section{Introduction}

Watural disasters "are often frightening events and difficult for us to understand because they strike indiscriminately and we have no control over them. They can bring sorrow
and devastation, but they can also become life-changing experiences that teach important lessons about what is important and about the fragility and joy of life" (Woods, West, Buettner \& Usher, 2014, p. 10). The authors of this paper recount their experiences of probably Far North Queensland's most prominent natural disasters - cyclones:

I arrived in Cairns in January of 2000 and was followed two weeks later by Cyclone Steve. Coming from the sub-arctic, I was familiar with blizzards of intense snow, freezing temperatures and dangerously icy roads. The idea of a cyclone was new to me. With advice from my boss, I gathered supplies and my small family (my 11 year old son and small dog) in the most sheltered part of our rental home, where we listened faithfully to the battery-operated radio, occasionally peeking out the door trying to discern what was happening outside. We huddled together, in fear and uncertainty, and I wondered why I had made the decision to move to this foreign environment.

The next day, palm fronds and branches covered our garden and pool. The power failure meant we had a freezer's worth of food that had to be eaten or disposed 
of quickly. Neighbours, probably understanding the newness of the experience to us, came round and helped with the clean up, staying for a barbecue to cook the thawing food. I felt many things at once: relief, joy, bewilderment and ongoing anxiety with the realisation that this cyclone weather world was what I'd accepted when I signed my employment contract.

The cyclone season from November to May is a very exciting time for me. Our family are great "weather frogs!" ; every one of us has a go at predicting how strong the cyclone will be and which direction it will take when coming closer to the coast.

Our fascination with the weather began some years ago...My husband built a yacht and together with our three children we sailed around the world. It took us 12 years. Our safety depended on our weather observations because at that time we could not get any weather forecast.

Now living in Cairns, Far North Queensland, we watch the barometer closely; observe it fall from kilopascal (kPa) 1200 to 998 to 929 (Category 5); see a million trees act like fountains in the heat of the day; follow the gathering of cumulus clouds and watch when they begin a swirling dance in the area of the Solomon Islands. Then a cyclone is declared, a name is given and it takes on a character of its own, almost like a personality. This is an exciting time as tensions build up, life gets hectic and irritating: ... it is almost a relief when the cyclone hits the coast!

Woods, West, Buettner and Usher note: "Peoples' lived experiences of a severe weather disaster such as a cyclone have rarely been described from an individual perspective" (2014, p. 2). However, this research in Far North Queensland aims to reveal some of these perspectives, through examination of children's drawings and narratives that have emerged as a result of the cyclonic experience; and through this process to further understand the impact of tropical cyclones in Far North Queensland. Woods et al. (2014) state that, "a holistic understanding of cyclone survivors' experiences is proposed as a way to better understand how cyclones affect peoples' lives"' (p. 2). Further, Gibbs, Mutch, O'Connor and MacDougall, suggest for future research: "There is a need for critically informed exploratory studies that include children's perspectives on the role of children in disaster contexts, given the increased incidence of disasters resulting from the global forces of climate change" (2013, p. 129). This research, from a larger study, "Drawing through Disaster: Young Children's Art Work Responses to Crises", attempts to highlight children's voices in their descriptions of their lived experiences of the disaster of cyclones.

Children living through cyclones and floods might develop "Acute Stress Disorder" (ASD), which is related to "Post Traumatic Stress Disorder" (DSM IV) (Woods et al., 2014, p. 9). Concerned researchers Wooding and Raphael (2004) note that "posttraumatic reactive phenomena may be common in school children, but may go unrecognized by teachers or other adults who regularly spend time with them" (p. 11). McDermott, Berry and Cobham (2012) also confirm that, "little research had been dedicated to examining the relationship between the social environment and post-disaster post-traumatic stress disorder (PTSD) in children" (p. 109).

It is often assumed that children are more resilient to trauma or "unaffected because they may not show the same response pattern as adults" (McDermott et al., 2012, p. 13). Yet such concepts as conscious and unconscious fears, hopes, trauma, conflicts and fantasies have been found to reveal much about what children are feeling and experiencing (Cox, 1992; Di Leo, 1983; Kavanagh, 1998; Kolbe, 2005; Krenz, 2004; Malchiodi, 1998). 
In the aftermath of 2006's Cyclone Larry, mothers in Far North Queensland collected art work, poems and stories created by children in the area to express their experiences (Mothers Helping Others (MHO). The publication, Cyclone Larry: Tales of survival from the children of North Queensland (2006) contains 97 pieces of art work and narratives. This research includes interpretation of the work produced, using the Content-Interpretive-Developmental (CID) method, (Haring, 2012) to understand how children express their emotions and their personality through their work. Findings to date regarding the CID method suggest that art and narratives gave children a voice through which to express feelings, as well as being a tool for healing and encouraging children's resilience by involving them as mediators and not victims (Gibbs, Mutch, O’Connor \& MacDougall, 2013).

\section{Cyclones Defined}

In Queensland, weather is the focus of a lot of conversation. For example, Tourism Queensland's catch phrase to lure visitors, often in the wake of floods and cyclones, speaks of the weather: "Queensland - beautiful one day, perfect the next". In everyday greetings, the weather, along with the person's wellbeing, is generally a topic of discussion. It may be, as Wright (in Jordan, 2011) suggests, that "The Australian preoccupation with climate and weather comes from 'remnants of a deeply held and felt ancient belief"," (p. 28). Surely, cyclones and their manifestations have helped to build these beliefs.

According to the Bureau of Meteorology, "Tropical Cyclones are low pressure systems that form over warm tropical waters and have gale force winds (sustained winds of $63 \mathrm{~km} / \mathrm{h}$ or greater and gusts in excess of $90 \mathrm{~km} / \mathrm{h}$ ) near the centre" (Australian Bureau of Meteorology $[\mathrm{ABM}]$, n. d.). Destructive winds, which can range from 90 to almost $300 \mathrm{~km} / \mathrm{h}$, extend over many hundreds of kilometres and are usually accompanied by heavy rain, flooding and storm surges (Ibid). Cyclones are also referred to as hurricanes or typhoons and feature an 'eye' or centre of light winds surrounded by a cloud ring of strong winds and heavy rainfall. Deriving from tropical sea temperatures above $26.5^{\circ} \mathrm{C}$, they can be longlasting and are known to frequently change paths and escalate or dissipate (Ibid). The strength of a cyclone is measured in categories from 1 to 5 . Category 1 has gales less than $125 \mathrm{~km} / \mathrm{h}$, while category 5 can have very destructive winds with more than $280 \mathrm{~km} / \mathrm{h}$. Connected to the damaging windforce is often a storm surge, metres high, that can flood low-lying coastal areas and together with extensive rainfall can produce widespread flooding when the cyclone moves inland (MHO, 2006).

Cyclones are endured, but often dreaded in tropical regions such as Far North Queensland. Memories, and often myth, of their destructive effects permeate written, visual and spoken text from and about this area. For example, Kamenev notes of Cyclone Yasi that year (2011), Thousands of people were evacuated from Cairns after fears the city could take a direct hit. In the end, Yasi's path had Mission Beach, near Cardwell, and the World Heritage-listed Hinchinbrook Island in mind. It flattened sugar cane and banana crops, huge areas of trees and many buildings, though no one was killed. The cyclone was so powerful that it didn't complete disperse until it reached the centre of Australia, near Alice Springs. It's estimated Cyclone Yasi cost $\$ 3.6$ billion of damage - the most costly cyclone in Australia to date. Weatherwise, Australia is a continent of controversies, with weather-patterns that change from devastating drought, lasting several years, to immense flooding in a month's time (Carbone \& Hanson 2012). Scientists have traced these conditions back to the influence of 'E1 Nino" or 'La Nina', developing during different seasons and enduring from one to eight years. Cyclones are related to El Nino and La Nina climate drivers. During La Nina, 
considered the 'positive' part of the weather cycle, conditions are wetter and cooler; cloudiness and cyclones more frequent (Australian Bureau of Meteorology (ABM, n.d.). La Nina (Spanish: The girl child) events show a warmer Pacific Ocean stream and airflow towards Australia which can produce cyclones and extreme flooding (Agnew P \& F Association, 2011). La Nina events do not always follow El Nino events, and no two seasons are ever the same in onset, intensity or length of time.

The La Nina conditions that developed in 2010-2011 have been the strongest on record and produced a category 5 cyclone, Cyclone Yasi. Flooding from this cyclone resulted in the loss of 20 lives in the State of Queensland, as well as 30 towns being swamped and billions of dollars of damage (McDougall, 2011).

'El Nino' (Spanish: The Christ Child) is noticed by the fishermen of Peru around Christmas when warm waters of the Pacific flow in an eastward direction (Agnew P \& F Association, 2011), away from the Australian continent. El Nino is characterised by sustained periods of warming, higher temperatures, less rain and reduced numbers of cyclones (ABM, n.d.). But, as Walker (in La Canna) cautions, "While El Nino is typically associated with fewer cyclones and a later start to the season, there has never been a cyclone season without at least one tropical cyclone crossing the Australian coast".

Cyclones and floods in the State of Queensland have intensely affected people's lives (McDougall, 2011, p. 13). Not only is the experience of living through these natural disasters disturbing and traumatic, but people also have to struggle with cleaning up the mess, [as the water carries mud and sewage along into houses] and rebuilding, which might take years (Ibid) because "possessions, homes, equipment and friendships" may have been swept away (Mannix, 2012, p. 66).

\section{The Cyclone in Stages: Lead up, Landfall and Lessons Learned}

When talking about cyclones, people often refer to them as staged processes. For example, Emergency Management Australia (http://www.bom.gov.au/cyclone/about/tcchecklist.shtml) offers advice to the public of procedures to follow in the three stages of a cyclone: the lead up; when the cyclone makes landfall, and after the cyclone has ceased. In the lead up, or preparation for the cyclone, they advise such things as checking the walls, roofs and eaves of the home and trimming trees near the home; clearing the property of loose items that hit by wind might turn into missiles, and preparing an emergency kit, with key items and emergency contact numbers. When the cyclone makes landfall, they suggest disconnecting electrical appliances and using a battery-powered radio to listen to weather updates. They further suggest sheltering in protected areas, with mattresses and blankets, and waiting for the 'all clear' announcement. Following the cyclone they recommend checking for gas and electrical faults; avoiding damaged power lines; clearing fallen trees and helping neighbours to clear up (Ibid).

Emergency Management Australia's three stages correspond to stages evident in this research; stages we have named: Lead Up; Landfall: and Lessons Learned. Each of these stages is discussed below. 
Stage 1 - Lead Up

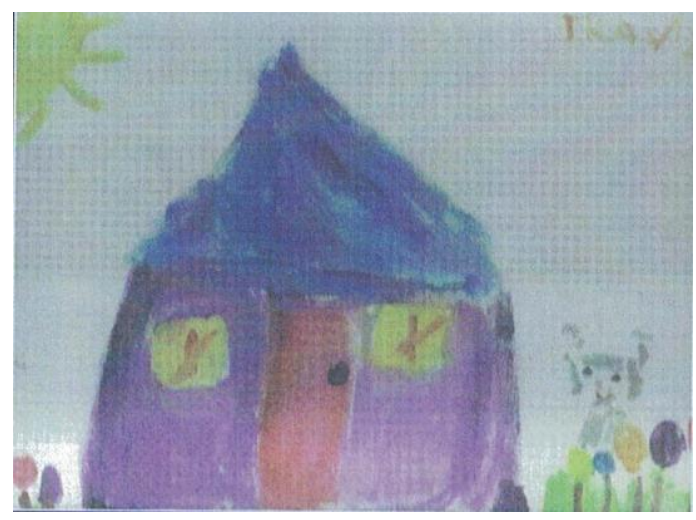

(MHO, 2006, p. 27)

On the day before the cyclone we had to tape up all of our windows (MHO, 2006, p. 82). First we removed all tin and other objects that could cause damage. Then dad cut down all the old white ant eaten trees. Then last of all we boarded up the windows and tied things down (MHO, 2006, p. 10).

The main source of energy for tropical cyclones is the warm oceans in the tropical regions. To initiate a tropical cyclone the sea-surface temperature generally needs to be above $26.5^{\circ} \mathrm{C}$. However, existing cyclones often persist as they move over cooler waters. The development of a tropical cyclone also relies on favourable broad-scale wind regimes and can persist for several days with many following quite erratic paths. They lose their source of energy when they move over land or colder oceans causing them to dissipate. Weakening may also occur if the cyclone moves into an unfavourable wind regime which disrupts the structure of the system. Sometimes a decaying tropical cyclone may interact with a weather system in higher latitudes to cause impacts far from the tropics (Australian Government, Geoscience Australia, http://www.ga.gov.au/scientifictopics/hazards/cyclone/basics/causes)

King, Goudie and Dominey-Howes noted of Cyclone Larry, "the people [around Innisfail] prepared for the cyclone season on the basis of personal knowledge and previous experience" (2006, p. 54). Children, while sometimes overlooked, did actively take part in this cyclone preparation, helping their parents with shopping for emergency supplies; clearing yards to avoid loose objects becoming airborne; and packing suitcases in case of evacuation (MHO, 2006). One eleven year old recounted: "We went shopping and got food, water and sticky tape. We had to move all pot-plants so they didn't blow away" (Ibid, 71). Another eleven year old commented, "Would the cyclone really come or had we done all that work for nothing? Well we'd just have to wait until tomorrow" (Ibid, 10).

Children, while waiting for the cyclone to arrive, observed happenings around them: "There were blue skies and no wind but all our animals were acting strangely" (11 year old, Ibid, p. 84). Children seemed worried as anxious parents reassured them to be brave. One four year old recalled: "I was brave because I was just really brave. I am not scared of nothing" (Ibid, p. 9). In the lead up to a cyclone, children often feel that they are at the mercy of elements beyond their control, wondering if they will survive (Woods et al., 2014). An 11 year old noted, "I was worried. I kept saying to Dad, 'Am I going to die?" (MHO, 2006, p. 9). This sentiment was reflected by a 12 year old, who reported: "We all thought we were going to die!'” (Ibid, p. 28). 
They observed their parents and watched their reactions to the continuous cyclone warnings: "Dad had turned on the radio wishfully thinking that maybe Larry had decided to change direction but to their disappointment Larry was still on his way and was now looking at making landfall closer to Innisfail” (MHO, 2006, p. 26).

Dogan-Ates commented that younger children "have the most limited repertoire of coping strategies; they are often influenced by the reactions of their parents and other family members" (2010, p. 471). During Cyclone Larry, children responded to the atmosphere around them, feeling the anxiety of their parents, when "go [ing] to sleep, not knowing what the morning might bring" (MHO, 2006, p. 1). According to Woods et. al. (2014) one mother reported,

"Our little Jack Russell pup was the first of showing signs of being frightened, and his anxiety, along with mine, just grew and grew like the noise, which was the hardest thing for me to deal with" (p. 5).

A 10 year old boy reported that, "the radio made an alarm and the man said that the cyclone had just grown to category 5. It was then that my mum got worried" (MHO, 2006, p. 54).

Stage 2 - Landfall

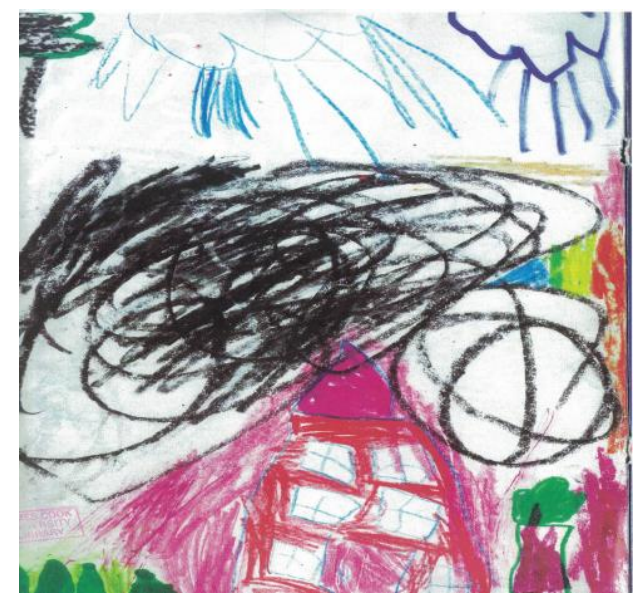

(MHO, 2006, intro)

We had to yell to hear each other over the screaming of the wind (MHO, 2006, p. 53).

The devastation was terrible, trees, poles, signs and post boxes were either blown away or knocked over. Powerlines were down and there was no power or phones (MHO, 2006, p. 80).

Landfall, when the cyclone reaches land, has been portrayed in both factual and fictional texts. In Great Australian Floodstories (2012), Mannix describes how, when the cyclone hits land, people hiding under beds heard the immense noise of strong winds; trees crashing, and rooftops being blown away. They waited anxiously when the winds calmed, as the eye of the cyclone passed over. With power-lines down and trees over roads, children had to stay inside with water leaking through broken windows and their toys and clothes soaking wet.

In this research, children described how they were watching what was happening outside during the cyclone. An 11 year old said, The cyclone started with an eerie rumbling, like a jet, but it didn't stop. We made out that the noise must be the wind blowing from above. Then we started to feel the effects, the wind started to blow, trees started to fall, then the power went out. All that was on was the battery operated radio (MHO, 2006, p. 10). 
Children reported facts: the roller-doors flying off; trees snapping; the roof lifting; embellishing them with the deluge of feelings caused by the destruction. A 12 year old said, I looked out further into one of the paddocks. There was our roof! The loud ripping noise was our roof ripping off. The hallway looked like a lap pool! Most rooms were flooded but mine was the worst. I was so upset. Everything was destroyed, nearly all the things in my room got wet, books, posters, my CD player and my bed (MHO, 2006, p. 28).

A five year old reported: "My fence fell down and my garage." (MHO, 2006, p. 16). The noise of the cyclone was overpowering as one 11 year old remembered, "The wind was so fierce that you couldn't even hear the trees cracking or twisting halfway up" (Ibid, p. 10). Children also recounted what was happening inside during landfall, as they hid in hallways, bathtubs, under beds and in cupboards; sitting on mattresses, holding cushions and toys and clutching each other:

I hid in the wardrobe and Dad stayed in the house. Mum stayed in the wardrobe with me and Brodie. We had lots of cuddles (5 year old, MHO, 2006, p. 16).

There was (sic) holes in our roof and all the water came in and we were scared and we were crying. Mum said "Don't be scared, be brave" (5 year old, Ibid, p. 29).

During the eye of the storm, Mum urged us to get on the couch where we played with toys and games to distract us from the destruction outside (8 year old, Ibid, p. 27). "I was feeling excited but terrified at the same time" (11 year old, Ibid, p. 70).

Some children noted that their parents prayed at the height of the storm: "Outside Mum and Dad were praying, we weren't allowed to go on the veranda so I went to the kitchen, had some biscuits, then went back to sleep" (12 year old, MHO, 2006, p. 13).

During landfall, windows can be broken, leaving glass splinters everywhere, and stormwater and mud can enter the house. One four year old commented, "My house had the windows broken. The hard wind blew the door in. I was hiding in the bathroom sitting on a mattress with my pillow. Mum and dad were with me and my sister" (MHO, 2006, p. 12). A ten year old recounted, "The dining room window exploded. Mum searched my body for glass before even looking at herself. When she was finished I moved into a corner and tried so hard to stop shaking" (Ibid, p. 25).

Children recounted that people outside of the cyclone zone, contacted their families: "Just then the phone rang and Mum went out very carefully to answer it. It was my grandfather calling to see if we were okay" (10 year old, Ibid, p. 25). They reported anxiety:

Everything was moving. The cyclone was in the house and things were crashing all around us. The bookcase fell over and the books were sent flying under the bed hitting us as the four of us huddled together in terror. The walls swayed and collapsed as gusts rammed and tore at them and Ifelt the house shuddering through the floor. The mattress over the bed lifted and we struggled to hold it down but couldn't. We ran through the debris, jumping moving furniture and dodging objects as they whipped past us. Around 7:30 the wind stopped ...we ran barefoot for 2 kilometres through cane, banana and cattle paddocks to our nearest neighbour (12 year old, Ibid, p. 53). 
Stage 3 - Lessons Learned

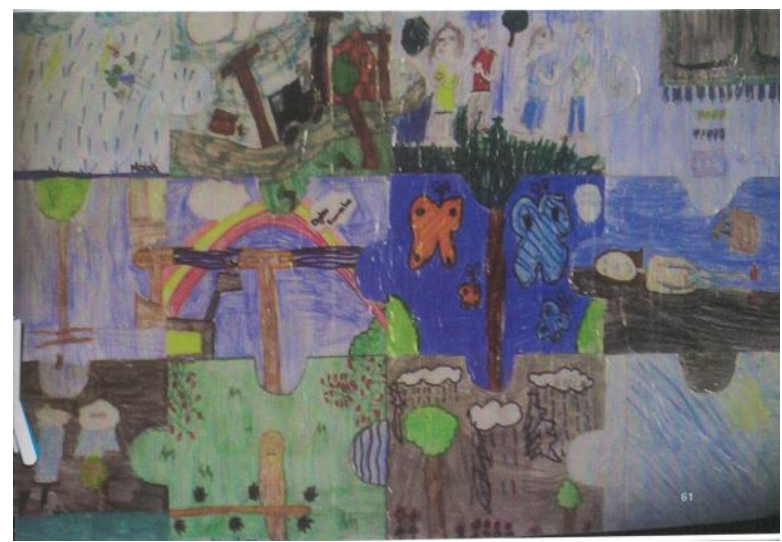

(MHO, 2006, p. 61)

There were butterflies... after the cyclone...lots of birds and wallabies hopping... and cassowaries sneaking across the road with their chicks all cheerful" (MHO, 2006, p. 57).

The aftermath of a cyclone is a time of clean up and rebuilding (Mannix, 2012). It is also a time of reflection as worlds change and people draw on inner strengths to reconstruct their lives. Mark Mitchell, Humanitarian Programmes Coordinator for Caritas at the time of Cyclone Pam in Vanuatu, noted, "What struck me most about the situation was the resilience of the people. Despite all they have gone through, they are simply getting on with the business of rebuilding their homes and livelihoods" (Caritas Aotearoa New Zealand, 2015). Woods et al. (2014) explain of the cyclone aftermath: "Overnight, the survivors' world was completely changed; leaving an unknown world in its place that would never be the same" (p. 5). Following the cyclone, children demonstrated changes to their perceptions - of life, their parents, the community and natural events. A 14 year old stated:

Cyclone Larry changed my life forever. Everything that my family owned was destroyed in a few short hours... We spent many days in the rain, searching the paddocks and salvaging what we could. We found some special jewellery, teddy bears and some clothes but there were very few other things we could recover. I still don't like showing people our "after Larry" photos. They seem inadequate and only show a few small parts of the bigger picture (MHO, 2006, p. 53).

Children seem to experience trauma because of the destruction of their personal environment. Woods et al. (2014) state: "In the immediate aftermath of a disaster--the acute post-disaster phase--stress, grief, depression, anxiety, and dissociative symptoms are all normal reactions to an abnormal situation" (p. 1). An 11 year old commented, "I know many lives have been turned upside down" (MHO, 2006, p. 73). A 12 year old recalled: "All in all the cyclone had done a lot of damage to our house, our street and our town. The lasting effects are that a lot of people lost their jobs, like my Mum, it will take a lot of years for our community to recover" (MHO, 2006, p. 17).

Many children lost their homes and possessions. Friends were also lost, due to some families needing to relocate to liveable premises and often different schools. They also experienced the loss of the usual conveniences like shopping, having a water supply and electricity: "It was three days before we could get out. We had to bathe in the local creek for a week before the power was back on" (12 year old, Ibid, p. 79). Children reported that nature, while lifegiving, can also be destructive: "It was very scary to feel nature's fury and how powerful and 
destructive nature is. WHO WOULD THINK NATURE WOULD BE SO CRUEL?” (Ibid, p. 40).

Woods et al. (2014) describe this as a "feeling of not being in control of their lives or their destiny, and of being at the mercy of a fearsome and violent force of nature" (p. 6). One 11 year old recalled, "Mum and dad...they were more scared than I was" (MHO, 2006, p. 42) and another one stated that when "the roof was wrenched from our house Mum and Dad joined us under the bed" (MHO, 2006, p. 53). Wooding and Raphael (2004) add, "In addition to profound psychological effects, an encounter with death or disaster may impact upon a child's sense of safety in the world" (p. 14).

Children also may have learned that enduring a cyclone can be an asserting experience: "Survivors were reminded of the fragility of life and consequently appreciated life more than before the cyclone... finding an inner strength and resilience that were unknown before" (Woods et al., 2014, p. 6). This reinforces the importance of family, and being together. A 10 year old reported, "We had no roof on our house, no walls, no beds, no toys, not a lot of anything left but no one was hurt in our family. We were still all together and that is all that matters to me" (MHO, 2006, p. 73).

Children observed that the community helped each other and that outside help came with police, army, volunteers and charities: "During the clean up it was very kind of people to help us. This included the army, SES volunteers, government workers and fellow community residents" (12 year old, MHO, 2006, p. 17). Woods et al. (2014) report, "Although survivors experienced extreme vulnerability and a threat to life, the disaster also brought communities closer together and connected family, friends, and neighbours through the caring, support, and help they offered each other" (p. 1).

Another lesson reported is that life goes on after disasters. Wooding and Raphael state, "For, while children may lose their innocence, they need not lose their belief and hope for a positive future" (2004, p. 19). A 16 year old reported: "It has been amazing to see people from all around Australia reach out to us with so much love and kindness and because of all the kindness and generosity; we really are beginning to get back on track" (MHO, 2006, p. 63). Children's artwork appeared as puzzle pieces coming together again, showing rainbows, butterflies and birds. "After the cyclone there were butterflies galore and animals came out everywhere. Wallabies and frogs were around" (11 year old, Ibid, p. 80).

From all work examined, only one child, an 11 year old, demonstrated concern about future cyclones, stating that she hoped one would not occur again soon. Her reasons were the destruction of nature and cost of rebuilding. "I do not want to go through another cyclone ever again because they make so much damage and cost millions of dollars to fix" (MHO, 2006, p. 72). Further, some younger children alluded to 'magical power': A 6 year old stated: "It was so windy but I had two lucky coins, so I saved the house" (Ibid, p. 27) and a three year old said, "I was scared but I had my two teddy bears" (Ibid, p. 37). A four year old child assured: "My dinosaurs scared LARRY away; they roared" (Ibid, p. 39).

\section{Summary and Conclusion}

The cyclone season, which lasts from November to May, is a dreaded time in Far North Queensland. Depending on El Nino or La Nina conditions in the Pacific Ocean, cyclones usually develop during this time in the area of the Solomon Islands. They might be unpredictable in their path, erratic, varying in strength and can be extremely destructive. 
In 2006, Cyclone Larry hit the Queensland coast and the children of Innisfail and surrounds experienced some life changing moments. Parents involved the children in the three stages of the cyclone: the lead up required extensive preparation; the landfall was a frightening experience for most children, and the aftermath, or lessons learned led to physical work during the clean-up and rebuilding of the damaged environment. Further, psychological insights and personal growth were apparent at each stage.

Children's voices gave a clear indication of their involvement: hope, fear and parental encouragement were reported in the lead up to Cyclone Larry, while they actively helped with shopping and tidying the house and yard. Parents' anxieties impacted on children's perceptions; particularly younger children. During landfall children observed their surroundings, recounting damage outside the house and inside, while constantly observing their parents' behaviour of coping with the disaster. Some children's worlds were dramatically changed, as houses were destroyed and families had to relocate to different areas and schools.

Lessons learned were many. Children demonstrated changes to their perceptions of life, their parents, their community and natural events. Some seemed to realise that their parents were not omnipotent, and others demonstrated fear, but the majority seemed to conclude that nature can be destructive but also life giving. Most children seemed to express that living through the cyclone was an asserting event, which gave them inner strength and resilience. They recognized the importance of family and working together with community, police, army and charities during the aftermath of the cyclone.

Research suggests that art and narratives give children a voice to describe their feelings and insights after a disastrous event (Wooding \& Raphael, 2004). Children's voices must be listened to and not be overlooked, as they are an important part in the overall picture of the cyclone experience.

\section{Works Cited}

Agnew P \& F Association (2011). Flood. Horror and tragedy. Agnew P \& F Association Inc. of Agnew School: Southern Education Managements.

Australian Bureau of Meteorology (ABM) (n.d). Accessed 12 October 2015 at http://www.bom.gov.au/?ref=hdr.

Australian Government, Geoscience Australia. Accessed 13 October 2015 at http://www.ga.gov.au/scientific-topics/hazards/cyclone/basics/causes.

Carbone, D. \& Hanson, J. (2012, March 8). Floods: 10 of the deadliest in Australian history. Australian Geographic, retrieved from: http://www.australiangeographic.com.au/topics/history-culture/2012/03/floods-10-ofthe-deadliest-in-australian-history/

Caritas Aotearoa (2015). Caritas humanitarian coordinator reflects on aftermath of Cyclone Pam. Retrieved from: http://www.caritas.org.nz/newsroom/media-releases/caritashumanitarian-coordinator-reflects-aftermath-cyclone-pam. 
Cox, M. (1992). Children's Drawings. London: Penguin Books.

Di Leo, J. H. (1982). Interpreting children's drawings. New York, NY: Brunner-Routledge.

Dogan-Ates, A. (2010). Developmental differences in children's and adolescents post disaster reactions. Issues in Mental Health Nursing, 31(7), 470-476.

Gibbs, L., Mutch, C., O’Connor, P., \& MacDougall, C. (2013). Research with, by, for and about children: lessons from disaster contexts. Global Studies of Childhood, 3(2), 129 -141 .

Haring. U. Exploring content, interpretation and development-Making sense of children's drawings. (Unpublished dissertation). Cairns, Qld: James Cook University: 2012.

Jordan, D. (2011). Heeding the warnings: 'Sucking up the seas' in Vance Palmer's Cyclone. etropic 10, 20-31.

Kamenev, M. (2011, February 2). Australia's worst cyclones: timeline. Australian Geographic, retrieved from: http://www.australiangeographic.com.au/topics/scienceenvironment/2011/02/australias-worst-cyclones-timeline.

Kavanagh, F. (1998). Stages of drawing and intelligence. Military Family Institute of Marywood University. Retrieved from http://www.dtic.mil:1998.

King, D., Goudie, D. \& Dominey-Howes, D. (2006). Cyclone knowledge and household preparation - some insights from Cyclone Larry. The Australian Journal of Emergency Management, 21(3), 52 - 58.

Kolbe, U. It's not a bird yet. The drama of drawing. Byron Bay, Australia: Peppinot Press: 2005.

Krenz, A. (2004). The secret of children's pictures. Retrieved from http://www.waldorflibrary.org

La Canna, X. (2015, October 12). Fewer cyclones expected this season over northern Australia as 'Godzilla' El Nino takes hold. Retrieved from ABC Net: http://www.abc.net.au/news/2015-10-12/fewer-cyclones-expected-this-season-overnorthern-australia/6840094: 2015.

Malchiodi, C.A. (1998). Understanding children's drawings. New York, NY: The Guilford Press.

Mannix, I. (2012). Great Australian Floodstories. Australia: Harper Collins.

McDermott, B., Berry, H., \& Cobham, V. (2012). Social connectedness: A potential aetiological factor in the development of child post-traumatic stress disorder. Australian \& New Zealand Journal of Psychiatry, 46(2) 109-117. 
McDougall, K. (2011). Using volunteered information to map the Queensland Floods.

Proceedings of the Surveying and Spatial Sciences Biennial Conference 2011, 21-25 November, Wellington, NZ.

Mothers Helping Others. (2006). Cyclone Larry. Tales of survival from the children of North Queensland. Australia: Mothers Helping Others Inc.

Wooding, S., \& Raphael, B. (2004). Psychological impact of disasters and terrorism on children and adolescents: experiences from Australia. Retrieved from http://pdm.medicine.wisc.edu

Woods, C., West, C., Buettner, P., \& Usher, K. (2014) "Out of our control”: Living through cyclone Yasi. International Journal of Qualitative Studies on Health and Well-Being, 9, 19821-32. doi:10.3402/qhw.v9.19821 